\title{
Serological, clinical and epidemiological aspects of Lyme borreliosis in Mures County, Romania
}

\author{
Aspecte serologice, clinice şi epidemiologice ale borreliozei Lyme \\ în judeţul Mureş, România
}

\author{
Brîndușa Țilea ${ }^{1}$, Grațiela Tripon ${ }^{2}$, Septimiu Voidăzan ${ }^{3}$, Ioan Țilea ${ }^{3 *}$ \\ 1. University of Medicine and Pharmacy Tirgu Mures, Romania, Department of Infectious Diseases \\ 2. Tîrgu Mureș Clinical County Hospital, Department of Laboratory \\ 3. University of Medicine and Pharmacy Tirgu Mures, Romania
}

\begin{abstract}
Lyme borreliosis (LB) is the most frequent infection transmitted by ticks from the Ixodes genus, both in the United States of America (USA), and in Europe. The objectives of this study were the monitoring of the incidence and clinical manifestations of the disease in Mures County, Romania. Material and method. The study was conducted over a period of two years, January 1st 2010 -December 31st 2011, on a number of 120 consecutive patients. The definite or probable diagnosis of LB was established on the Centers for Disease Control and Prevention (CDC, Atlanta, USA) criteria, and on the European Union Concerted Action on Lyme borreliosis (EUCALB). ELISA and Western-Blot techniques were used for identification of $\operatorname{IgM}$ and $\operatorname{IgG}$ antiBb from the serum and CSF. Results. There were 44 cases in 2010 and 76 cases in 2011. According to the case definition, 106 cases were confirmed as $L B$ and 14 were probable. LB was more frequently diagnosed in children, young adults and adults, compared to the over 60 years old age group. The incidence of disease was higher in women patients, 68 (56.66\%) compared to men - 52 patients (43.33\%), with a higher proportion in people coming from an urban setting, 78 patients (65\%), compared to people coming from rural settings 42 patients (35\%). Clinical manifestations were acute, like erythema migrans (EM) in $64.16 \%$ of the patients, neurological in $22.5 \%$ of the patients, joint related in $1.66 \%$ of the patients and cardiac in $0.83 \%$ of the cases. Conclusions. In Mures County we have observed an increased incidence of this disease in 2011 vs. 2010. The predominant clinical manifestations were the acute dermatological and neurological ones.
\end{abstract}

Keywords: Lyme borreliosis, serology, epidemiology, clinical aspects, Romania

\section{Rezumat}

Borrelioza Lyme (BL) este cea mai frecventă infecție transmisă de căpuşe din genul Ixodes, atât în Statele Unite ale Americii (SUA), cât şi în Europa. Obiectivele studiului au constat în monitorizarea incidenţei şi a manifestărilor clinice ale bolii în judeţul Mureș. Material şi metodă. Studiul s-a efectuat pe o perioadă de 2 ani, 1 ianuarie 201031 decembrie 2011, pe un număr de 120 pacienţi. Diagnosticul cert sau probabil al BL s-a stabilit pe baza criteriilor

*Corresponding author: Ioan Țilea, University of Medicine and Pharmacy Tirgu Mures, Romania, e-mail: i.tilea@ clicknet.ro 
Centers for Diseases Control and Prevention (CDC, Atlanta, SUA) şi European Union Concerted Action on Lyme Borreliosis (EUCALB) şi anume epidemiologice, clinice şi serologice. Pentru identificarea anticorpilor antiBb IgM, IgG din ser şi LCR s-au utilizat tehnicile ELISA şi Western-Blot. Rezultate. În anul 2010 s-au inregistrat 44 cazuri, iar în anul 2011, 76 cazuri. Conform definiţiei de caz, 106 cazuri au fost confirmate, 14 probabile. BL a fost evidenţiată cu o frecvenţă mai ridicată la copii, adulţi tineri şi adulţi, comparativ cu grupa de vârstă peste 60 ani. Incidenţa afecţiunii a fost mai ridicată la sexul feminin, 68 pacienţi (56,66\%) faţă de sexul masculin 52 pacienţi (43,33\%), cu o pondere, mai crescută la persoanele din mediul urban, 78 pacienţi (65,0\%), comparativ cu cele din mediul rural 42 pacienţi (35,0\%). Manifestările clinice au fost acute de tipul eritemului migrator (EM) la 64,16 din pacienți, neurologice la 22,50\% pacienţi, articulare la 1,66\% pacienţi şi cardiace la 0,83\% din cazuri. Concluzii. În judetul Mureș s-a constatat o incidenţă în creştere a bolii în anul 2011 comparativ cu anul 2010. Manifestările clinice predominante au fost cele acute dermatologice, neurologice.

Cuvinte cheie: borrelioza Lyme, serologie, epidemiologie, aspecte clinice, România

Received: $18^{\text {th }}$ October 2013; Accepted: 16 ${ }^{\text {th }}$ May 2014; Published: $25^{\text {th }}$ May 2014.

\section{Introduction}

Among the emerging transmissible disease with which mankind is confronted at the present time lies Lyme borreliosis (LB), a disease transmitted by arthropods from the Ixodes class, and produced by spirochaetes from the Borrelia burgdorferi $(\mathrm{Bb})$ genus sensu lato, clinically characterized by multisystem manifestations, with a step by step evolution and polymorphic symptoms and signs.[1] The pathogen conveyed by the tick initially induces pathological skin manifestations taking the form of erythema migrans (EM) accompanied or not by constitutional symptoms, thus realizing the primary stage of the infection. Once it passes through the cutaneous barrier the $\mathrm{Bb}$ spirochete is disseminated in the blood reaching the central (CNS) and peripheral (PNS) nervous system (leading to meningeal, encephalic, radicular and medullar lesions); the cardiovascular system (myopericarditis, different degrees of atrio-ventricular blocks); the joint system (arthritis) etc. [2,3]. The past two decades are marked by sustained research regarding the pathogenesis, immunology, clinical spectrum, diagnosis and prevention of the disease. The isolation of this bacterium is difficult, the LB diagnosis being based on serological methods with sensitivity and specificity limitations. The interpretation of these tests is not stan- dardized, and the positivity criteria applicable in the USA are not enforceable in Europe due to the differences among the genospecies present on these two continents [4].

In Romania, the vector of this illness is Ixodes ricinus, and, due to a steady increase in their number, the disease is surveyed, and it is reportable from 2007 [5].

The different clinical manifestations of LB proves the fact that the geographical distribution of this disease is not equal, residing probably from the different distribution of $\mathrm{Bb}$ genospecies in Europe (B. afzelii, B. garinii, Bb sensu stricto occasionally, $B$. spielmanii) compared to the USA, where Borrelia burgdorferi sensu stricto is the only pathogen species [6].

It is very difficult to estimate LB incidence in Europe due to testing patterns differences, underdiagnosis, varied serological diagnosis criteria, and proof of seropositivity in those with late exposure to $\mathrm{Bb}$, referring to those asymptomatic persons coming from endemic BL areas. On the other hand, there are some false positive reactions with a high level of antibodies but these are not specific to $\mathrm{Bb}$, but rather they might be due to a cross reaction with other conditions (infectious, immunological, neurological), leading to the risk of overdiagnosing the illness. In the light of these facts, it is highly recommended that the interpretation of the positive tests will consider 
the clinical and epidemiological context as well. After reviewing the conducted studies on this subject it is obvious that the prevalence of LB in European countries is variable, with an increase in prevalence from the west to the east of the continent [7]. In Romania, the areas with the highest number of reported cases of LB are in the central (where Mures county is located) and northern part of the country [9]. Depending on the amount of time between the infecting moment and the first clinical symptoms (skin, neurological, joints, cardiac), the CDC and the EUCALB classify the LB cases as acute and late and, according to the case definition, as confirmed, probable and suspect LB $[7,10]$.

\section{Material and methods}

The study was carried out over a period of 2 years, January $1^{\text {st }} 2010$ - December $31^{\text {st }} 2011$, on a number of 120 patients admitted and observed in the Infectious Diseases Clinic, Mures County Clinical Hospital. The patients' inclusion criteria were established in accordance with the CDC, the EUCALB and the Romanian National Center for Transmittable Diseases Surveillance and Control criteria; patients were assessed using epidemiological, clinical and serological criteria [7-10].

The epidemiological criteria included the existence of a tick bite or a trip in endemic areas in the patient history, influenced by the propensity of people to engage in outdoor pursuits in early summer.

Clinical criteria: the presence of erythema migrans (EM) at various sites of body skin, following a tick bite, with or without asthenia, fever, myalgia and other systemic symptoms; in patients with meningeal involvement the presence of the intracranial hypertension syndrome (headaches, nausea, vomiting, photophobia) and meningeal irritation symptoms (nuchal rigidity, positive Kerning I, II signs) were monitored. The presence of the following symptoms were mon- itored in patients with central nervous system (CNS) damage: sleepiness, decreased alertness, balance loss, vertigo, altered osteotendinous reflexes; in those patients with peripheral nervous system (PNS) damage the presence of radicular pain, palsies, cranial nerves palsies (facial, abducens, ocular palsies) etc. were noticed as well. In patients with joint involvement, the presence of joint inflammation and of joint and periarticular pain syndrome were encountered, and the existence of cardiac clinical signs (dyspnoea, arrhythmias) was noted in patients with cardiac involvement.

Serological examination followed the principles of a two-step approach: (1) a serological screening assay; and (2) in the event of a positive or equivocal result, a confirmatory assay.

For diagnosis confirmation, serum and CSF samples were analyzed using two different techniques of ELISA and immunoblotting, following the diagnosis algorithm recommended by the National Center of Surveillance and Control of Infectious Diseases [9].

The ELISA tests used for screening should be at least second generation tests that have been improved with respect to cross-reactivity with other bacteria (e.g. antigen extract with previous Reiter Treponema adsorption) or use purified intact flagella as antigen. We used Virion/Serion kits (Institut Virion/Serion Gmbh, Wurzburg, Germany), with the anti Bb IgM and IgG sensu lato considered positive if $\geq 11 \mathrm{U} / 1$, negative if $<9$ $\mathrm{U} / \mathrm{l}$; the heterogeneity of the immunodominant epitopes must be considered.

The recomLine Borrelia (Mikrogen ${ }^{\circledR}$ kit, Mikrogen Diagnostik, Neuried, Germany) is a qualitative in vitro test for detection of $\mathrm{IgG}$ and/ or IgM antibodies against Borrelia burgdorferi sensu stricto, B. garinii, B. afzelii and B. bavariensis and B. spielmanii in human serum, plasma or CSF on one single test strip: VlsE from different genospecies, OspC from all genospecies, p18 (Decorin binding protein $\mathrm{A}=\mathrm{DbpA}$ ) from all genospecies; it offers the same advantages as 
the Western blot - all relevant, pathogen specific antigens on a single test strip and therefore separate detection of the respective antibodies in a single approach. The recomLine is the method of choice for antibody avidity testing.

The recomLine Borrelia is used for confirmation of the samples that are positive or unknown in the screening test. It can also be used for detection of the human $\operatorname{IgG}$ and $\operatorname{IgM}$ antibodies formed intrathecally in the CSF (CSF/serum pairs). It facilitates secure identification of specific antibodies against selected antigens of human pathogenic Borrelia burgdorferi. Antibodies against certain antigens can give additional indications on the stage of the infection.

Highly purified recombinant Borrelia burgdorferi s. I. antigens (OspA, OspC, p100, VlsE, p39, p58 p18 (= DbpA, decorin-binding protein A), p41 (flagellin) are fixed on nitrocellulose membrane test strips. There are control bands at the upper end of the test strips:

a. The reaction control with the strip number that must show a reaction for every serum / plasma sample.

b. The conjugate controls (IgG, IgM) are used for the inspection of the antibody class detected.

c. "Cutoff control": The intensity of this band allows the assessment of the reactivity of each of the antigen bands

The test result is determined by adding the point values of the individual bands reactive over the cut-off (i.e. with a minimum grade of + ).

In assessing the antigens, a sum of points above or equal to 7 is considerate positive for $\mathrm{IgG}$ and IgM; a 6 points value is inconclusive and values equal to or below 5 are considered negative. A reaction with $\mathrm{OspC}$ is very characteristic for an early immune response (IgM). A strong reaction with the following bands mostly occurs in serums from late stages of the infection (IgG): p100, V1sE, p58, p39 and p18. On the contrary, antibodies against OspA are rarely found. The VlsE is a very early marker of the
IgG response, but also frequently accompanies the immune response in late manifestation of the infection, and occurs besides p100 and/ or p18.

The test has a diagnostic sensitivity for Lyme arthritis of $96 \%$; for acrodermatitis chronica atrophicans $100 \%$; for neuroborreliosis $94 \%$; for erythema migrans $79 \%$ and a $100 \%$ diagnostic specificity.

The test is not influenced by anticoagulants (citrate, EDTA, heparin, CPD), hemolysis or lipemia of the sample. False positive results occur in icteric serums.

Patients who had neurological symptoms (intracranial hypertension syndrome, meningeal syndrome, CNS and PNS), after a brain CT and a fundoscopic exam, underwent lumbar puncture and CFS was analyzed; the macroscopic and microscopic aspect of the CSF was evaluated: the pleocytosis $\left(>5\right.$ leucocytes $\left./ \mathrm{mm}^{3}\right)$, glucose and protein content. In order to prove intrathecal synthesis of anti Bb IgM and IgG antibodies, the CSF determinations were obtained simultaneously with the serum results; the antibody index was also calculated. To avoid the possibility of false positive reactions that might have appeared as a result of other illnesses (syphilis, tuberculosis, infectious mononucleosis, leptospirosis, HIV infection, autoimmune diseases, and multiple sclerosis), the patients' serums were tested accordingly.

Other tests: For the patients with neurological, meningeal or cerebral involvement specific techniques were performed (brain CT and MRI) that enabled structural evaluations in order to detect cerebral lesions; investigations were interpreted by neurologists and radiologists. Multiple sclerosis was refuted by the neurologist using the McDonald diagnostic criteria (2010/2011) [1-3]. Demographic aspects, the patients' originating environment and risk factors such as profession, travel to endemic areas were noted.

Patients with joint or cardiac involvement were examined by rheumatologists, cardiologists and were scheduled to perform joint MRI 
examinations, ECG's and echocardiography. Confirmed LB cases included the patients who met the serological, clinical and/or epidemiological criteria, while probable cases included patients who met the epidemiological and clinical criteria. Suspected cases were not included in the study.

Statistical analysis was performed using MedCalc Software (Version 12.3.0 bvba, Mariakerke, Belgium). Student test was used to assess differences between the means of continuous variables (expressed as mean $\pm \mathrm{SD}$ ), while the $\chi 2$ test was used for categorical variables (expressed as $\mathrm{n}(\%)$. All the tests were interpreted at the $p=0.05$ significance threshold and statistical significance has been considered for all values of $\mathrm{p}$ lower than the threshold.

\section{Ethical considerations}

The study was approved by the Ethics Committee of the University of Medicine and Pharmacy of Tirgu Mures, Romania and was performed in the accordance with standards of the Declaration of Helsinki. All study participants consented to the use of their clinical data for hospital research, and patients with a clear diagnosis of LB upon treatment or hospital admission were provided additional details about this particular study. Written informed consent for all medical maneuvers, including lumbar puncture was ob- tained from each patient or legal guardian if the patient was a minor. No procedures beyond the standard of care were performed specifically for the purposes of this study.

\section{Results}

The 120 patients of this study came from the Mures County, Romania. In 2010, 44 patients $(33.66 \%)$; were diagnosed with LB while 76 patients $(63.33 \%)$; were diagnosed in 2011. We have noticed a higher incidence of cases in children (5-17 years old, 28 patients $-23.33 \%)$; young adults (18-39 years old, 41 patients $34.16 \%$ ); and adults (40-60 years old, 35 patients $-29.16 \%$ ); compared to the over 60 years old age group (16 patients - 13.33\%);

The gender distribution has proven a predominance of this disease in women, 68 patients $(56.66 \%)$; compared to men, 52 patients $(43.33 \%)$;

Most of the cases were coming from urban settings, 78 patients (65\%); and 42 patients $(35 \%)$ coming from rural areas.

Only 12 patients $(10 \%)$ were part of the risk groups (animal caretakers, forest workers, farmers), the rest of 108 patients $(90 \%)$ could not be integrated in the above mentioned categories.

The tick bite was recognized in the recent history by 98 patients $(81.66 \%)$; EM was noticed by 77 patients $(64.16 \%) ; 28$ cases $(63.63 \%)$ in 2010, and 49 cases $(64.47 \%)$ in 2011. (Table I)

Table I. Distribution of clinical manifestations in Lyme borreliosis

\begin{tabular}{lccc}
\hline Clinical manifestations & $\mathbf{2 0 1 0}(\mathbf{n}: 44$ cases) & 2011 (n:76 cases) & "p" value* \\
\hline Erythema migrans (EM); $\mathrm{n}(\%)$ & $28(63.63)$ & $49(64.47)$ & 0.91 \\
\hline Acute meningitis; $\mathrm{n}(\%)$ & $10(22.72)$ & $11(14.47)$ & 0.36 \\
\hline Facial palsy; $\mathrm{n}(\%)$ & $2(4.54)$ & $0(0.0)$ & 0.25 \\
\hline Acute encephalitis; $\mathrm{n}(\%)$ & $1(2.27)$ & $1(1.31)$ & 0.73 \\
\hline Encephalomyelitis; $\mathrm{n}(\%)$ & $0(0.0)$ & $1(1.31)$ & 0.77 \\
\hline Radiculloneuropathy; $\mathrm{n}(\%)$ & $0(0.0)$ & $1(1.31)$ & 0.77 \\
\hline Joint involvement; $\mathrm{n}(\%)$ & $0(0.0)$ & $2(2.63 \%)$ & 0.73 \\
\hline Carditis; $\mathrm{n}(\%)$ & $1(2.27)$ & $0(0.0)$ & 0.78 \\
\hline *- chi square test & &
\end{tabular}


The most frequent symptoms encountered in the case of the 120 patients who were involved in the study were: asthenia (in $40 \%$ of the cases), headache $(30 \%$ of the cases), myalgia $(25 \%)$, arthralgia (22\%), fever (15\%), meningeal irritation syndrome $(10 \%)$, unilateral facial palsy $(1.6 \%)$, and other pathologic neurological signs (1.6\%), cardiac arrhythmias $(0.83 \%)$.

In the order of their frequency the clinical neurological manifestations were: acute lymphocytic meningitis (21 patients $-17.5 \%$ who also had meningeal syndrome), unilateral facial palsy ( 2 patients $-1.6 \%$ ), acute encephalitis ( 2 patients $-1.6 \%$ ), acute encephalomyelitis and poliradiculoneuropathy (one patient each $-0.83 \%$ ). There was a mean value of 300 lymphocytes $/ \mathrm{mm}^{3}$ in 10 patients with acute meningitis $(22.72 \%$ of the cases) diagnosed in 2010, and a mean value of 500 lymphocytes $/ \mathrm{mm}^{3}$ in 11 patients $(14.47 \%$ of the cases) diagnosed with acute lymphocytic meningitis in 2011. A statistically significant difference between average lymphocytes corresponding for patients diagnosed with acute meningitis in two years (Student test: p-0.01) was seen. The mean value of CSF lymphocytes in patients with meningitis enrolled in this study was 400 cells $/ \mathrm{mm}^{3}$. The CSF biochemistry (glucose and protein content) showed normal and similar values in the two years of study ( $p-0.43$ for glycorrachia respectively $\mathrm{p}-0.80$ for proteinorrachia). (Table II)

Early unilateral Lyme arthritis located at the knee was diagnosed in two patients $(1.6 \%)$, sustained by the epidemiological data (tick bite) and by the serological results from the synovial fluid obtained by joint puncture, preceded by the knee joint MRI examination. Both patients showed positive levels of $\operatorname{IgM}$ anti $\mathrm{Bb}$ antibodies in the synovial fluid (ELISA-viditest anti Borrelia recom $\operatorname{IgM}^{\circledR}$, MoBiTec GmbH, Gottingen, Germany) Lyme carditis with $3^{\text {rd }}$ degree atrioventricular block was diagnosed in one patient $(0.83 \%)$. An autoimmune myocarditis was excluded due to the immunological determinations, which were negative, to the lack of corticotherapy response and to the absence of structural cardiac involvement. The epidemiological and clinical data, and the presence of positive and dynamically increasing $\operatorname{IgM}$ anti $\mathrm{Bb}$ antibodies (IgM anti $\mathrm{Bb}$ antibodies: $26 \mathrm{U} / \mathrm{L} ; 54 \mathrm{U} / \mathrm{L})$, confirmed the etiological diagnosis.

It was prominent that the disease started during the warm season with a high incidence in summer months, followed by spring and autumn months both in 2010 and in 2011 (Fig. 1).

In the studied patients we have also followed the time span between the infection moment (the tick bite) and the date of arrival to our clinic, which has coincided with the onset of clinical symptoms, all of the patients being included in the acute stage of the disease. EM began within 10 to 21 days from the tick bite, with an average of 16 days, the neurological manifestations between 14 and 30 days, with an average of 23 days, the joint manifestations between 21 and 25 days, with an average of 23 days, and Lyme carditis with an onset at 28 days from the infection moment. The serological tests performed

Table II. Mean values (lymphocytes, glycorrachia, proteinorrachia) obtained from a number of 21 patients with acute lymphocytic meningitis

\begin{tabular}{lccc}
\hline & $\mathbf{2 0 1 0}$ & $\mathbf{2 0 1 1}$ & "p" value \\
\hline lymphocytes $/ \mathrm{mm}^{3}$ & $300 \pm 120^{*}$ & $\mathbf{n : ~ 1 1 ~ ( 1 4 . 4 7 \% )}$ & (22.72\%) \\
\hline glycorrachia $(\mathrm{mg} / \mathrm{dl})$ & $44.6 \pm 3.6$ & $500 \pm 200$ & $\mathbf{0 . 0 1 * *}$ \\
\hline proteinorrachia $(\mathrm{mg} / \mathrm{dl})$ & $37.9 \pm 4.7$ & $43.4 \pm 3.5$ & 0.43 \\
\hline
\end{tabular}

*- data were expressed as mean $\pm \mathrm{SD} ;{ }^{* *}$-test Student 


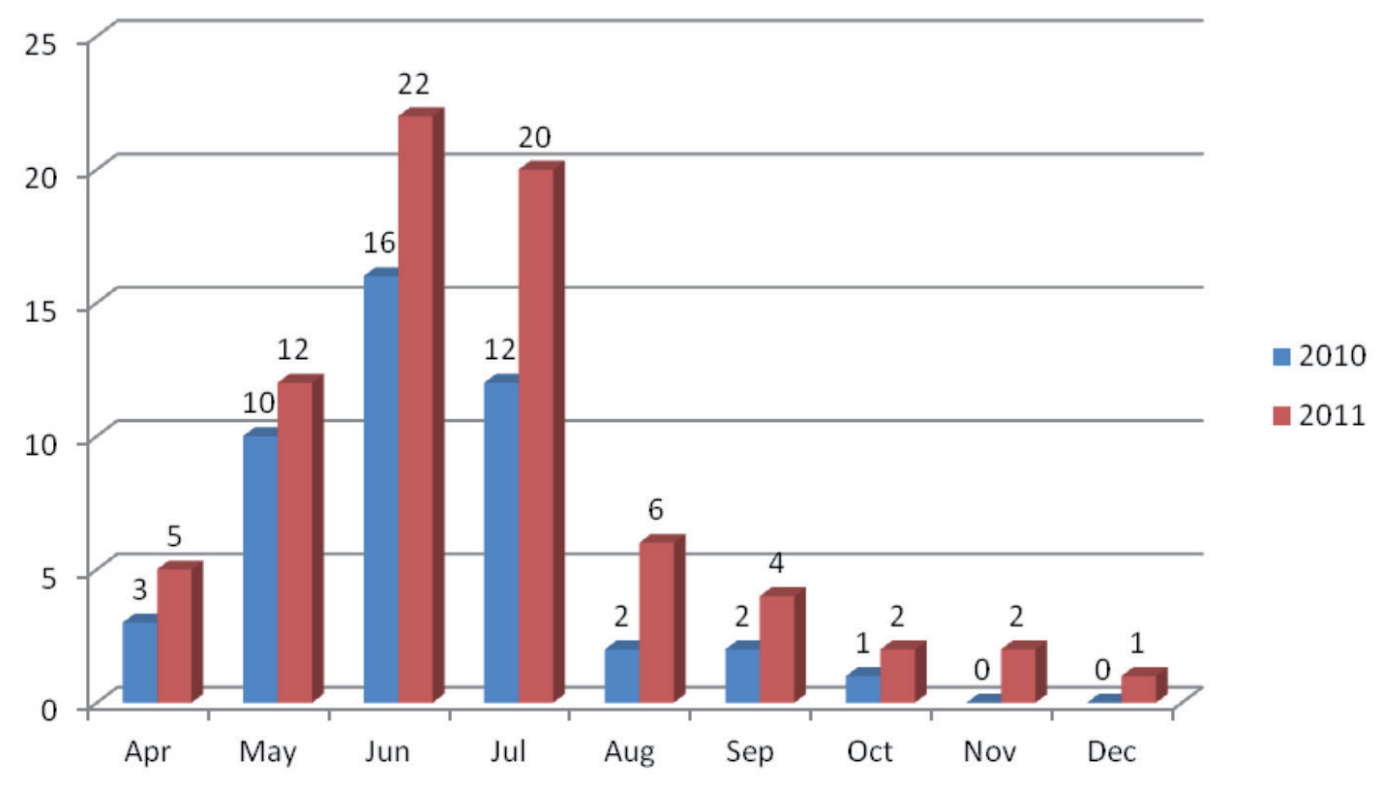

Figure 1. Distribution of patients depending on the onset month

(ELISA, immunoblotting) both from serum and $\mathrm{CSF}$ revealed antiBb IgM antibodies in all confirmed cases (106 - 88.33\%); 40 cases in 2010 $(33.33 \%)$ and 66 cases in 2011 (66.67\%). Correlating the epidemiological, clinical and serological data obtained in 2010 and 2011 respectively, it became apparent that all patients were diagnosed in the acute stage of LB; 40 patients with confirmed LB vs. 4 patients with probable LB in 2010, respectively 66 patients with confirmed LB vs. 10 patients with probable LB in 2011.

The LB incidence in Mures county (588,359 inhabitants) in 2010 was $7.47 \%$ inhabitants and in the following year $12.91 \%$ increasing with $4.64 \%$ in 2011 compared to the previous year.

\section{Discussions}

Lyme borreliosis is a widespread disease, with an endemic evolution and small epidemic outbreaks in virtually all affected regions.
Because of the predominance of asymptomatic forms of the disease and the impossibility and impracticality of performing all the laboratory tests needed for a positive diagnosis, LB almost certainly has a wider geographical spread than has been previously reported [6].

Mures County lies in the central-northern region of Romania, in the center of the Transylvanian highland, between $23^{\circ} 55^{\prime}$ and $25^{\circ} 14^{\prime}$ eastern longitudes and $46^{\circ} 09^{\prime}$ and $47^{\circ}$ northern latitude. The hilly and highland relief is present in more than $50 \%$ of the area, with altitudes ranging from $300 \mathrm{~m}$ above sea level in the Mures valley to a maximum of $2100 \mathrm{~m}$ on the ridge of the Calimani Mountains. The population is estimated to 588,359 inhabitants. Because of the favorable environmental and climate conditions more and more vector agents from the Ixodes genus emerged in the past two years, leading to an increase of the number of LB cases which, in turn, determined these cases to be monitored. $[5,11]$. 
As this study points out, the LB' incidence in Mures County showed an increase in 2011 compared to 2010 by $4.64 \%$ inhabitants, higher than the estimated incidence of LB in Romania which was $12.91 \%_{0000}$ in 2011 (National Centre for the Surveillance and Control of Transmissible Disease Bucharest, 2011) [9]. The increased incidence of BL in our area, compared to other regions of the country, is favored on one hand by the increased number of ixodes due to the favorable habitat (abundance of forests) and on the other hand, by the fact that in other regions, the disease could be underdiagnosed or unidentified due to the lack of monitoring and insufficient information provided to the population. [5,12]. But the incidence is relatively low compared to other European and neighboring countries, most likely due to the underdiagnosis of the disease. In Europe, a decrease of the LB' incidence from South to North in Scandinavia and from North to South in Italy and Greece was noted. The highest LB incidence was seen in the Baltic countries, Austria (130\% ${ }_{0000}$ inhabitants), Bulgaria (55\% inhabitants), Czech Republic (29\% inhabitants) and Germany $(25 \%$ inhabitants $[6,7]$.

The LB' incidence in Mures County and in our country is likely to be much higher, but this disease has only been reported since 2007 . Romanian seroprevalence studies were published in 1999 , found antibodies in $4-8 \%$ of the general population with a population risk of $9.9-31.7 \%$ [11].

A higher frequency of the disease was noted in children and young adults compared to the over 60-years-old age group. This is consistent with other published data: LB may appear at any age, but is more frequent in children and 30-50 years old adults [13].

Patients coming from an urban setting were predominant, an unsurprising fact as many recent studies note that emerging LB is losing its professional illness trait and tends to affect more and more people from an urban environment, due to the increasing number of vectors in these areas [14].

In this study the presence of morbidity was demonstrated predominantly in people who frequented green areas for leisure purposes. Cases were registered over the whole year, with an increase incidence from spring (April, May) to summer months (June, July) of 2010 as well as 2011; in August, September, and October a decrease in the number of cases was noted. This seasonal distribution of the disease is closely related with the critical onset of the maximum activity of the ixodes in our country because of its temperate climate. [5]. In the USA cases are reported all year round, probably due to the late forms of illness, acrodermatitis chronica atrophicans (ACA) and Lyme neuroborreliosis (LNB) which are independent of tick activity [15].

All patients included in the study have shown early manifestations of the disease, present in $\leq 30$ days from the tick bite; this fact is also supported by the anti $\mathrm{Bb}$ IgM acute phase antibodies both in serum and in CSF determined using the ELISA and Western-blot techniques that have proven a high sensitivity and specificity and by correlating the results with epidemiological and clinical data. Patients with negative serology were categorized as "probable LB" despite the fact that they presented suggestive clinical and epidemiological data, due to the fact that dynamic antibodies monitoring could not be performed because of the patients' absence in follow-ups.

According to medical literature, it is known that the acute phase antibodies (anti Bb IgM) do not appear in the first days after the infection, but only after approximately 21 days, and, sometimes after 30 days from the bite $[14,15]$.

In the years prior to this study in Mures county only 3 patients with late LNB were diagnosed; in our region early LB and LNB cases are prominent, maybe because of the on-time prophylaxis and recommendations made by the general practitioner (GP) and the Infectious Dis- 
ease Consultants who were approached by the patients who were stung or already showed the first signs of the illness. [16].

Erythema migrans with different locations (in the order of frequency: lower limbs, upper limbs, and torso) was noted in $64.17 \%$ of patients, but these have come for a consult mainly due to associated symptoms: asthenia, fever, myalgia, and arthralgia. Both in Europe and in the USA erythema migrans is the most important diagnostic criterion of LB [17]. Serological results in patients with early lesions are frequently negative but positive results do not prove EM because background seropositivity is high in some regions. Furthermore, prompt antibiotic treatment of this manifestation may ablate the antibody response. Serology does not contribute significantly to a diagnosis of EM [1].

Yet, in our study, $25.83 \%$ of the patients did not notice the presence of EM, but they acknowledged the tick bite.

Neurological manifestations were observed with an increased frequency (22.5\% of patients) compared to the USA which has reported a lower incidence (15-20\%) [18].

Acute lymphocytic meningitis was frequently diagnosed in children and young adults, a fact also highlighted by Halperin which underlines the fact that this determination represents the most frequent manifestation of early LNB [15]. The CSF was clear, and the release pressure was normal. Pleocytosis was not over 500 lymphocytes $/ \mathrm{mm}^{3}$ with an average of 400 cells/ $\mathrm{mm}^{3}$, and the CSF biochemistry showed normal values. The presence of CSF pleocytosis in the 21 patients with acute meningitis was correlated with the presence of antiBb $\operatorname{IgM}$ antibodies in the CSF and the serum, thus definitely proving the intrathecal presence of $\operatorname{IgM}$ index anti $\mathrm{Bb}$ antibodies and not their crossing from the serum through the blood-brain barrier in the subarachnoid space.
Unilateral facial palsy was observed in only two patients, although this is the most common neurological symptom in Finland, and the second in Europe after EM [19].

Facial palsy may be the first and only sign of early LB, accounting for $70-80 \%$ of all cranial nerve palsy in the early stage of the disease. The facial nerve involvement in our study was seen in a child and a young adult and was not accompanied by CSF pleocytosis, a clinical aspect known as acute meningoradiculitis or Bannwarth syndrome, the most typical manifestation of early LB [20].

The frequency of acute encephalomyelitis cases was low $(0.83 \%)$ compared to other European and American studies, where the frequency of this neurological clinical picture was higher [21].

The frequency of CNS manifestations in the USA is generally lower, these manifestations being more frequently reported in Europe, almost always accompanied by CSF pleocytosis and peripheral neuritis. The most frequent clinical picture is that of encephalomyelitis [22]. All our studied cases showed medium encephalic involvement consisting in sleepiness, confusion, vertigo, transient incontinence, sensibility and balance disorders. Brain CT and MRI in this category of patients did not show any major alterations, but in the two patients suffering from acute encephalitis brain CT detected a discreet diffuse cerebral edema. Cerebral structural alterations were noted by Albrecht et al. in $20 \%$ of the cases, confirming lesions located especially in the cerebral white matter [21].

Early Lyme arthritis is more frequent in the USA (it was at the basis of the discovery of this illness).

The bone and joint involvement in LB may become apparent at any age, but it has been more frequently seen in children at an early or late stage of the disease [23, 24]. In our study, it was diagnosed in two young adults that complained 
of arthralgia in one joint only (the knee), followed by joint swelling, symptoms that developed 20 days after the tick bite. The MRI exam showed joint fluid collection. The synovial and plasmatic serological determinations showed the presence of high levels IgM anti Bb antibodies. The first patient presented antibody serum level of the anti $\mathrm{Bb}$ IgM type of $28 \mathrm{U} / \mathrm{I}$ and $16 \mathrm{U} / \mathrm{I}$ in the synovial fluid and in the second case the serum level was of $22 \mathrm{U} / \mathrm{I}$ and $12 \mathrm{U} / \mathrm{I}$ in the synovial fluid. Following the rheumatology consult and immunological investigations a joint determined immunopathy was excluded. The joint pain syndrome and the acute inflammatory phenomena did not subside under "pain-killer" treatment or NSAID treatment, but only after etiological treatment. Considering the epidemiological context (the tick bite three weeks prior to articular symptoms), the clinical one (joint swelling) and the positive plasma and synovial fluid serology, as well as the remission of acute joint inflammation following antibiotic therapy, by excluding other etiologies, the cases could be interpreted as early-stage Lyme arthritis.

According to Wright (2012), the length of arthritis depends on its' onset age, being shorter in children compared to adults [2].

The incidence of carditis in North American patients is between 4 and $6 \%$, while in Europe this LB involvement is higher, $10 \%$ of them being early. LB carditis manifests most frequently by conduction disturbances, various degrees of atrioventricular block, but also myocarditis, pericarditis and dilated cardiomyopathy [25]. Lyme carditis with $3^{\text {rd }}$ degree atrioventricular block non-responsive to cardiologic therapy was diagnosed in a single young patient, who had EM history and was part of the risk groups (farmer) and who presented 28 days after the EM dyspnoea, arrhythmias and one episode of syncope, for which he was admitted to a cardiology clinic, with a $3^{\text {rd }}$ degree atrioventricular block and a junctional rhythm of $35 \mathrm{bpm}$. A possible autoimmune myocarditis was refuted based on the immunological determinations, but a high titer of $\operatorname{IgM}$ anti $\mathrm{Bb}$ antibodies was noted in the patient's serum. The patient's evolution was slowly favorable after the initiation of etiological treatment, but the lesions were considered to be irreversible and the patient had to undergo a bicameral pacemaker implantation procedure, this case being the only diagnosed and declared case of cardioborreliosis in Mures County.

Conduction abnormalities with varying degrees of atrioventricular conduction defects are typical manifestations.

In particular, Lyme carditis should be suspected in younger individuals showing conduction abnormalities without other apparent risk factors, and who have a history of recent exposure to ticks $[26,27]$.

\section{Conclusions}

The LB incidence in the Mures County is rising. In our study, LB did not have the character of a professional disease, being proven the presence of morbidity in urban patients that have frequented green areas for leisure purposes. The disease was more frequent in children and adults, the prominent clinical manifestations being the acute skin and neurological ones. Antibody detection methods are mainly used in the setting of Lyme borreliosis diagnosis and should be performed in specialized laboratories.

\section{Acknowledgements}

This paper is partially supported by the Sectoral Operational Programme Human Resources Development financed from the European Social Fund and by the Romanian Government under the contract number POSDRU/89/1.5/S/64109.

\section{Author Disclosure Statement}

The authors have nothing to disclose. No competing financial interests exist. 


\author{
Abreviations \\ ACA - Acrodermatitis chronica atrophicans \\ $\mathrm{Bb}$ - Borrelia burgdorferi \\ CDC - Centers for Diseases Control and Preven- \\ tion \\ $\mathrm{CI}$ - Confidence interval \\ CNS - Central nervous system \\ CSF - Cerebrospinal fluid \\ CT - computed tomography \\ EKG - electrocardiography \\ ELISA - Enzyme Linked Immunosorbent Assay \\ EM - Erythema migrans \\ EUCALB - European Union Concerted Action \\ on Lyme borreliosis \\ GP - General practitioner \\ HIV - Human immunodeficiency virus \\ LB - Lyme borreliosis \\ LNB - Lyme neuroborreliosis \\ MRI - Magnetic resonance imaging \\ NSAID - Non-steroidal anti-inflammatory drug \\ Osp - Outer surface protein \\ PNS - Peripheral nervous system
}

\section{References}

1. Stanek G, Fingerle V, Hunfeld KP, Jaulhac B, Kaiser R, Krause A, et al. Lyme borreliosis: clinical case definition for diagnosis and management in Europe. Clin Microbiol Infect. 2011 Jan;17(1):69-79 DOI: 10.1111/j.1469-0691.2010.03175.x

2. Wright WF, Riedel DJ, Talwani R, Gilliam BL. Diagnosis and Management of Lyme disease. Am Fam Physician. 2012 Jun 1; 85(11):1086-93

3. Wormser GP, Brisson D, Liveris D, Hanincora K, Sandigursky S, et al. Borrelia burgdorferi genotype predicts the capacity for hematogenous dissemination during early Lyme disease. J Infect Dis. 2008 Nov 1;198(9):1358-64 DOI: 10.1086/592279

4. Wormser GP, Dattwyler RJ, Shapirro ED, Halperin JJ, Steere AC, Klempner MS, et al. The clinical assessment, treatment, and prevention of Lyme disease, human granulocytic anaplasmosis and babesiosis: clinical practice guidelines by the Infectious Diseases Society of America. Clin Infect Dis. 2006 Nov 1;43(9):1089134 DOI: $10.1086 / 508667$

5. Coipan EC, Vladimirescu AF: Ixodes ricinus ticks (Acari: Ixodidae): vectors for Lyme disease spirochetes in Romania. Exp Appl Acarol. 2011 Jul;54(3):293-300 DOI: $10.1007 / \mathrm{s} 10493-011-9438-4$

6. Lindgren E, Jaenson TGT: Lyme borreliosis in Europe. Influences of climate and climate change, epidemiology, ecology and adaptation measures, World Health Organization, Regional Office for Europe, Copenhagen, Denmark. 2006;5-24 [http://www.euro.who.int/_data/ assets/pdf_file/0006/96819/E89522.pdf]

7. European Concerted Action on Lyme Borreliosis. Diagnosis: Case Definition EUCALB: [http://eucalb.com/]

8. Wilske B, Fingerle V, Schulte-Spechtel U. Microbiological and serological diagnosis of Lyme borreliosis. FEMS Immunol Med Microbiol. 2007;49(1):13-21. Review DOI: 10.1111/j.1574-695X.2006.00139.x

9. Centrul Naţional de Supraveghere şi Control al Bolilor Transmisibile - Boala Lyme - metodologie de supraveghere: Lyme borreliosis. [http://www.insp.gov. ro/cnscbt/index.php?option=com_docman\&task=cat_ view\&gid=34\&Itemid=10] [in Romanian]

10. Centers for Disease Control and Prevention United States: Effect of electronic laboratory reporting on the burden of Lyme disease surveillance: New Jersey, 2001-2006. MMWR. 2008 Jan;57(2):42-5

11. Hristea A, Hristescu S, Ciufecu C, Vasile A: Seroprevalence of Borrelia burgorferi in Romania. Eur J Epidemiol. 2001;17(9):891-6 DOI: 10.1023/A:1015600729900

12. Semenza JC, Suk JE, Estevez V, Ebi KL, Lindgren E. Mapping Climate Change Vulnerabilities to Infectious Disease in Europe. Environ Health Perspect. 2012 Mar;120(3):385-92 DOI: 10.1289/ehp.1103805

13. Stanek G, Strle F. Lyme borreliosis: a European perspective ondiagnosis and clinical management. Curr Opin Infect Dis. 2009 Oct;22(5):450-4 DOI: 10.1097/ QCO.0b013e32832ee880

14. Rizzoli A, Hauffe HC, Carpi G, Vourch GI, Neseler M, Rosa R. Lyme borreliosis in Europe. Eurosurveillance. $2011 \mathrm{Jul} ; 16(27): 1-6$

15. Halperin JJ, Shapiro ED, Logigian EL, Belman AL, Dotevall L, et al. Practice parameter: treatment of nervous system Lyme disease (an evidence-based review). Report of the Quality Standards Subcommittee of the American Academy of Neurology. Neurology. 2007 Jul;69(1):91-102 DOI: 10.1212/01. wnl.0000265517.66976.28

16. Țilea B, Chiriac C, Țilea I, Urcan R, Tripon G, Gliga M. Diagnostic, therapeutic and evolutive particularities of Lyme disease. Rev Romana Med Lab. 2009 Jun;15(2):55-60

17. O'Connel S. Lyme borreliosis: current issues in diagnosis and management. Curr Opin Infect Dis. 2010 Jun;23(3):231-5 DOI: 10.1097/ QCO.0b013e32833890e2

18. Ljostad U, Skogvoll E, Eikeland R, Skarpaas T, et al. Oral doxycycline versus intravenous ceftriaxon 
for European Lyme neuroborreliosis: a multricentric, non-inferiority, double blind, randomised trial. Lancet Neurol. 2008 Aug;7(8):690-5 DOI: 10.1016/S14744422(08)70119-4

19. Smith R, Takkinnen J. Lyme borreliosis: Europe-wide coordinated surveillance and action nedeed? Euro Surveill. 2006 Jun;11(6):E060622.1

20. Skogman BH, Glimåker K, Nordwall M, Vrethem M, Ödkvist L, Forsberg P. Long-term clinical outcome after Lyme neuroborreliosis in childhood. Pediatrics. 2012 Aug;130(2):262-9 DOI: 10.1542/peds.2011-3719

21. Albrecht P, Henke N, Lehmann HC, Macht S, Hefter $\mathrm{H}$ et al. A case of relapsing -remitting neuroborreliosis? Challenges in the differential diagnosis of recurrent myelitis. Case Rep Neurol. 2012 Jan;4(1):47-53 DOI: 10.1159/000337223

22. Fallon BA, Levin ES, Schweitzer PJ, Hardesty D. Inflammation and central nervous system Lyme disease. Neurobiol Dis. 2010 Mar;37(3):534-41. DOI: 10.1016/j.nbd.2009.11.016
23. Wormser GP, Nadelman RB, Schwartz I.The amber theory of Lyme arthritis: initial description and clinical implications. Clin Reumatol. 2012 Jun;31(6):989-94 DOI: 10.1007/s10067-012-1964-x

24. Puius YA, Kalish RA. Lyme arthritis: pathogenesis, clinical presentation, and management. Infect Dis North Am. 2008 Jun;22(2):289-300 DOI: 10.1016/j. idc.2007.12.014

25. Costello JM, Alexander ME, Greco KM, Perez AR, Laussen PC. Lyme carditis in children: presentation, predictive factors, and clinical course. Pediatrics. 2009 May;123(5):835-41 DOI: 10.1542/peds.2008-3058

26. Lo R, Meuzies DJ, Archer H, Cohen TJ.J.Complete heart block due to Lyme carditis: Invasive Cardiol. 2003 Jun;15(6):367-9

27. Koene R, Boulware DR, Kemperman M, Konety SH, Groth M, et al. Acute hearth failure from lyme carditis. Circ Heart Fail. 2012 Mar;5(2):e24-6 DOI: 10.1161/ CIRCHEARTFAILURE.111.965533 